\title{
Role of Financial Institutions in Making the Capital Formation in Jordan for the Period 1978-2010
}

\author{
Ruba Abu Shihab ${ }^{1}$ \\ ${ }^{1}$ Faculty of planning \& Management, Al-Balqa' Applied University, Jordan \\ Correspondence: Ruba Abu Shihab, Faculty of planning \& Management, Al-Balqa' Applied University, P.O. \\ Box 130, 11733, Amman, Jordan. Tel: 962-797-634-519. E-mail: yshatha@gmail.com
}

Received: December 26, 2013

Accepted: February 7, 2014 Online Published: February 21, 2014

doi:10.5539/ijbm.v9n3p111

URL: http://dx.doi.org/10.5539/ijbm.v9n3p111

\begin{abstract}
This study aims to analyze the role played by financial institutions to influence the levels of investment in Jordan for the period 1978 to 2010, through the study of the role of each of the banking sector and stock market, this study used the equilibrium model that takes into account both the supply and demand to achieve the objectives of the study. As the least squares method has been used through the three stages to estimate the simultaneous equations. The results confirmed the importance of the banking sector and the stock market in influencing the levels of investment in Jordan.
\end{abstract}

Keywords: financial institutions, investment, the equilibrium model, banking sector, financial stock exchange market

\section{Introduction}

\subsection{Explore the Importance}

Modern theories of economic development confirm the importance of providing adequate funding, especially in the early stages of development to achieve high rates, and with the beginning of the seventies came the writings of both Shaw and McKinnon, which emphasized the critical importance of financial policy in influencing the growth and development, and leading financial institutions to play an active role in accelerating economic growth and achieving high growth rates for its ability to mobilize savings and efficiency of the employed and to direct towards investments with high-yield to provide competitive returns regarding the depot, in addition to its role as an intermediary in passing monetary policy, as a result of these institutions a role in providing funds for projects in new investment by using different kinds of tools for new opportunities in innovation, creativity and technical development and financing of production for export and the establishment of the infrastructure which is reflected in the provision of jobs and address poverty and unemployment and to improve the competitiveness and economic growth. The role of financial institutions is reducing the risk of economic activity through the insurance sector and its ability to provide information and to reduce the cost and the cost of transactions, as well as to diversify the investment portfolio. Accordingly, and based on the above comes the importance of studying of the role of financial institutions in influencing the level of investment in Jordan, this will focus this study and highlight the role of financial institutions in Jordan.

\subsection{Hypothesis}

The first hypothesis:

The existence of sophisticated financial institutions is influenced by the level of investment in Jordan.

The second hypothesis:

The existence of developed market securities are influenced by the level of investment in Jordan.

\section{Previous Research}

The role of financial institutions according to the growth in different kinds of economies throughout our research is because of its great importance, and the followings are examples as shown below:

O. Alao and L. Raimi, (2011) explore the role of financial institutions in the escalation of the global economic melt-down (GEM) in America and how policy-makers in Nigeria can learn from South Africa to safe-guard the 
nation's financial institutions from economic shocks that could be propelled by banks' financial recklessness and poor corporate governance ethics. They find the potency of financial regulation and supervision to forestall economic melt-down; the potency of financial regulation and supervision to safe-guard a nation's financial institutions from financial recklessness and promote good corporate governance.

The purpose of the study (Soufan, 2008) is to study the source of economic growth in Jordan and whether the growth has been expanded by increasing the amount of input factors of production or growth depending on intensive growth. As the study identifies the impact of financial sector development in stimulating the rate of economic growth. Also the study shows the results of growth that depends on the growth expanding with the improvement in the productivity of all factors of production.

The study (Tang \& Donny, 2006) have shown the impact of financial sector development on economic growth of countries (APEC) for the period from 1981 to 2000, focusing on the role of each of the stock market and banking sector and capital flows. According to the results that showed among the three sectors of the stock market that have a strong influence on economic growth, especially in the developed countries of the sample.

The (Fisman \& Raymond, 2004) study analyzed the relationship between financial development and economic growth (in industry sector). As the study used a measure of the level of industry (technology) that is based on a scale Zengales(1998), We have emerged from the study that the existence of different effects of these indicators on industrial growth depend on the level of financial development in different countries.

The (love \& Inessa, 2002) study is to show the relationship between financial sector development and the behavior of dynamic investment by using the model (VAR) and using the cross-sectional data for 36 countries, as the study confirmed the impact of financial factors on investment.

While the (Claessens \& Laeven, 2002) study show the cross-sectional data of the value added of a number of countries and showed that improved asset allocation and return to a better property rights leading to higher economic growth.

The (Alalaween, 1998) study aim to analyze the impact of bank credit provided by licensed banks to economic fluctuations and the results showed the presence of a complementary relationship between GDP and credit facilities and also showed that the impact of credit on output is positive in the short and long run.

The (Levine \& Ross, 1997) study aim to analyze the effects of financial sector development on economic growth, as the study concluded that the theories of financial and empirical evidence suggests the existence of the Association of a strong and positive relationship between the role of the financial system and economic growth.

The (king \& Levine, 1993) study show the relationship between the extent of financial sector development and economic growth for the period from 1960 to 1989 , and the study showed that the impact of financial development on income growth rate is constant and regular.

Our study will address the role of financial institutions, focusing on both the banking sector and stock market in influencing the level of investment in Jordan using a general equilibrium model for the period of the year (1978) and up to the year (2010).

\section{Theoretical Framework}

Jordan has witnessed during the past four decades a great development in various economic fields. The period of the seventies boom unprecedented as it made economic growth rates high, arrived in the Jordanian economy to a state close to full employment, but this performance soon began to retreat since (1982), where the economy has declined until the late eighties, the period of the year (1990) and up to the year (2007) were more periods of competing events and changes witnessed this period, the real beginning of the implementation of a comprehensive economic reform and was the beginning of the state of recovery in the Jordanian economy.

All branches of economic activity for the time being depend on financial services, which constitute large and growing of economies and is a sound financial system and stable of the things necessary for the continuation of economic growth, and therefore, any weakness in the financial sector can be racked out of growth and development.

Financial market concept derives from the concept of the market in general. Although the stock markets are compared to other commodity markets, relatively recent, but it preceded the other markets both in terms of organization and in terms of capabilities and facilities available to clients because of the magnitude of financial investments that are exchanged in these markets. The increased economic role of stock markets and the so-called term exchanges have become so scattered all over the world. 
Because of the flexibility of the great characteristic of the financial market has expanded the scope of this market has also increased its depth, for example, the presence of local and regional financial markets because of the tremendous progress achieved in the modern means of communication on the one hand, due to the ease of exchange of securities on the other hand, it has become easier for those who treat them in any spot in the world to perform in a few minutes a huge financial deals in the global financial markets by means of telex, phone or the Internet while sitting in his office. But the financial markets like other markets, vary in the level of effectiveness and efficiency, depending on the varying capabilities and financial facilities and human resources available to each of them, and researchers agree on the investment in the presence of important indicators fit used as a measure of the efficiency of the financial market.

First: the low cost of exchange in the financial market, means that the costs of financial transactions for this feature is provided in the event of an indicator of internal efficiency of the financial market.

Second: the speed of adaptation or response to the prevailing prices to new information that is available to customers in it. This property is an indicator of the efficiency of the foreign financial market.

The modern theories of economic development emphasizes the importance of the availability of adequate funding, especially in the early stages of development to achieve high growth rates and the credit is provided by the banking system, the foundation stone in bringing about the changes necessary for development. With the beginning of the seventies came with writings of both Shaw and Miknon (Al-majali, 2003), which confirmed the importance of policy, funding and the consequent channeling savings to investment, infrastructure, efficiently, since the policy of finance has great importance in influencing the growth and development, and that any shortcomings in the provision of funding needed is an impediment to growth and lead to adverse effects on the production and use of economic resources, therefore, the expansion of funding is provided for supporting the growth and help the economy to achieve high rates of production and use.

In the view of (Al-majali, 2003) the monetary and financial institutions play an important role in economic development through the followings:

- Channeling savings to investment: where the monetary institutions and brokers are in the compilation of savings and made available to investors in the form of loans of different maturities and thus increase the volume of investments in a positive impact on economic development.

- Diversification in investment: Some of the monetary and financial institutions offer investors economic pre-feasibility studies for their projects, these institutions provide appropriate advice to those investors and the types of investment opportunities available to low-risk, ensuring these institutions recover their debts.

According to Patrick (Al-majali, 2003) the provision of adequate financial resources for investments by commercial banks opens the prospects of thinking businessmen and occurs creative responses that blow up their energy and makes them think better in the establishment of new projects or expansion projects and thus require the more business to loans and move the economic situation state control of the display to the case of follow-up demanding in increasing the supply of loans that result in increasing of demands, as in Japan. Patrick also finds that the impact of the financial system in economic growth will be from the following areas:

- The existence of financial institutions working on re-distribution of wealth in a manner that provides the necessary funds to invest, instead of the concentration of wealth in the form of land or cattle or stock of grain, gold, silver that helps a financial institutions to redistribute in other forms.

- The existence of financial institutions working on re-distribution of new investments from economic sectors with low productivity to sectors with high productivity. Investors, businessmen are usually those with the talents and experience in the investment and focus on investment in projects with high productivity while savers may invest their money in productive projects.

Those who study the literature of financial and banking can see very clearly the privacy enjoyed by the intermediary financial institutions, where the highlight of this Privacy debut in the role to be played by banks in the development of solutions to the problem of asymmetric information through its ability to provide information needed by investors in the ability to distinguish between good credit risks and non-good, where you can get money from depositors and lending institutions and therefore the collection of larger profits, allowing them to engage in the activity of providing information. and highlights the special role of banks also in their ability to enter into loan contracts efficiently and to tune according to these contracts effectively and to minimize the risk that may result from the inability of the client to repay the loan, this is due to the ability of banks to enter into such contracts inefficiently for two reasons, first is the ability of banks to renegotiate in to the agreements on loans more easily and are cheaper than the lenders ordinary bearers bonds, while the second 
reason goes back to the banks usually in large stake in the institutions and the various projects which invites them to set controls repeatedly to make sure whether there is violation in any contract or agreement.

The flexibility of banks to lend institutions are affected by one of the most important factors that give the banks their privacy where we can see that in the absence of the organization's ability to pay and breach of contracts with the bank, there for the banks' ability to restructure the credit contracts, and the restructuring of contracts, made banks work to reduce the financial cost of the failure of institutions unlike other lenders who lack this ability, flexibility, and forcing institutions to bankruptcy.

\section{Quantitative Analysis}

Quantitative analysis will be determined by the mathematical and econometrics model indicating the data used and methodology of the econometrics analysis. Form to achieve the objectives of this study to clarify the role of financial institutions in influencing the levels of investment in Jordan by building an economic model that includes both the supply and demand, which was used in the study based on the model of Bernanke, Gentler and Gilchrist.,and it will be used in the least-square way of the (3-stage) and that should be noted that added variables related to the financial sector, which is the cornerstone of this form to the equation of investment, and that includes the form to (26) variables of which (6) variables internal and (20) external variables as follows:

Table 1. Internal variables in the econometrics model

\begin{tabular}{ll}
\hline $\mathrm{Yt}$ & GDP \\
\hline $\mathrm{Ct}$ & Private consumption \\
$\mathrm{It}$ & Private investment \\
$\mathrm{Ht}$ & Work \\
$\mathrm{Gt}$ & Government consumption \\
$\mathrm{t} \mathrm{MD}$ & The demand for money \\
\hline
\end{tabular}

Table 2. Exogenous variables in the econometrics model

\begin{tabular}{ll}
\hline $\mathrm{Q}_{-1 t}$ & The index of industrial production quantities for one period of delay \\
\hline $\mathrm{C}_{-1 t}$ & Private consumption for one period of delay \\
$\mathrm{K}_{\mathrm{t}-1}$ & Total capital for one period of delay \\
$\mathrm{R}_{\mathrm{t}}$ & The real interest rate \\
$\mathrm{P}_{\mathrm{t}}$ & The general price level \\
$\mathrm{W}_{t}$ & Real wages \\
$\mathrm{G}_{\mathrm{t}-1}$ & Government consumption for one period of delay \\
$\mathrm{N}_{\mathrm{t}-1}$ & The market value of companies listed on the Stock Exchange for one period of delay \\
$\mathrm{Yd}_{\mathrm{t}}$ & Disposable income \\
$\mathrm{H}_{\mathrm{t}-1}$ & Demand for labor for one period of delay \\
$\mathrm{MS}_{\mathrm{t}}$ & Money Supply \\
$\mathrm{T}_{\mathrm{t}}$ & taxes \\
$\mathrm{RR}_{\mathrm{t}}$ & The proportion of trading volume to GDP\% \\
$\mathrm{V}_{\mathrm{t}}$ & The percentage of market value to GDP \% \\
$\mathrm{PRV}_{t}$ & The proportion of facilities granted to the private sector to GDP\% \\
$\mathrm{PR}_{t}$ & The proportion of facilities for non-financial institutions to domestic credit\% \\
$\mathrm{D}_{t}$ & Financial depth\% \\
$\mathrm{B}_{t}$ & The proportion of the assets of the licensed banks to the banking system's assets \\
$\mathrm{X}_{t}$ & Gross profit added to the cost \\
$\mathrm{TB}_{t}$ & Account balance of trade \\
\hline &
\end{tabular}

\subsection{The Demand Side}

\subsubsection{Function of Private Consumption (Ct)}

The Keynesian theory of theories that addressed the consumption function, since this theory was born precisely during the period which show the emergence of a crisis of global recession in 1929. Keynes showed the consumption function, is stable in income, as Income is the major determinant in consumer spending, and thus 
linking Keynes between consumption and income in the form of a simple function called through which the relationship between consumer spending and income is known as Marginal propensity to consume.

The theory of angel law, has to link the per capita income of the structure of spending, through the fluctuations in income (at different levels) affect on consumer spending for individuals, the more income percentage spent on food, in contrast is characterized by the proportion of spending on (percentage spent) on clothing and household items relatively stable with increasing income, while increasing the proportions allocated to spend on luxury goods and services as well as increasing the percentage spent on education and health.

This has been the implementation of the relationship between per capita income and consumer spending on a particular commodity curve known as the angel curve, in order to analyze and study of the relationship between per capita income and consumer spending on a commodity or several commodities.

Finally, the theory of Milton Friedman called the theory of permanent income in his book (the theory of consumption function) in 1957 to emphasize the consumption is associated with positive consumption in the previous period (Ct-1).

Accordingly, and based on the above consumption function can be derived as follows:

$$
C_{t}=b_{1}+b_{2} C_{t-1}+b_{3} Y d_{t}+\varepsilon_{1}
$$

It depends positively on disposable income ( $\mathrm{Yd}$ t), consumption in the previous period (Ct-1).

Where points $\left(\varepsilon_{1}\right)$ to random error variable.

\subsubsection{Function of Private Investment (It)}

The investment of the most important components of aggregate demand, as a stone is an essential impact on production and income and then the rate of economic growth. Has addressed the economic theories of different function investment analysis, that has been associated with the study function of investment before the advent of Keynesian theory of capital formation optimized by the development based on Irving Fisher in 1930 as it turns out that the facility is seeking to maximize the present value, under perfect competition by continuing to invest in all projects of which the present value is positive in the context of the interest rate market. Fisher showed the continuation of the business as long as the rate of investment return is greater than interest rate (Kiswani, 1997).

The Keynesian theory show an inverse relationship between the level of investment and the interest rate, and take the investment decision according to this theory by comparing the interest rate with the marginal efficiency of capital.

- The literature emphasizes the financial impact of the financial sector on the levels of investment in the economy, as financial sector development leads to stimulate investment levels, and notes to the financial literature that it can measure the evolution of the financial sector through a number of indicators including: (Soufan, 2008).

- Financial depth (Dt), which is an indicator of the size of financial intermediation, where the more higher the relative size of the reverse provide greater liquidity and greater financial depth and thus greater development in the banking system.

- Credit facilities granted to non-financial institutions from the private sector to total domestic credit facilities (PRt), which reflects the share of non-financial corporations to the private sector credit.

- Percentage of credit facilities granted to the private sector to the GDP (PRVt), which reflect the role of banks in financing private sector activity.

- percentage of assets of the licensed banks to the total assets of licensed banks and the Central Bank (Bt), which reflects the importance of banks and their contribution in the allocation of savings.

- Volume for the annual gross domestic product (RRt), which reflects the volume of trading relative to the size of the economy.

The annual trading volume for the total annual market value $(\mathrm{Vt})$, which reflects the volume of trading for the stock market. Accordingly, the investment function can be derived as follows:

$$
I_{t}=b_{4}+b_{5} B_{t}+b_{6} R R++b_{7} D_{t}+b_{23} P R R_{t}+b_{24} P R V t_{t}+b_{25} V_{t}+b_{26} R_{t}+\varepsilon_{2}
$$

It depends negatively on the interest rate (Rt), and positively on the extent of financial sector development indicators measured the previous six. Where points $\left(\varepsilon_{1}\right)$ to random error variable. 


\subsubsection{Function of Government Consumption (Gt)}

Support of government consumption in the economy also suggests economic theories positively income tax (Tt) (Quraan, 1988), which was considered a variable externally being determined based on management decisions in spite of its reliance on economic activity and income, and GDP (Yt) as well as consumption government in the previous period (Serry, 1987) Gt-1 as follows:

$$
G_{t}=b_{8}+b_{9} Y_{t}+b_{10} T_{t}+b_{11} G_{t-1}+\varepsilon_{3}
$$

Where points ( $\varepsilon_{1}$ ) to random error variable.

4.1.4 The Equation of the Real Sector Tariff

$$
\begin{aligned}
Y_{t}=C_{t}+I_{t}+G_{t}+T B{ }_{t} \\
\mathrm{Yd}_{\mathrm{t}}=\mathrm{Y}_{\mathrm{t}}-\mathrm{T}_{\mathrm{t}}
\end{aligned}
$$

Where points (TBt) to the trade balance, which was considered a variable externally despite the assumption our study the case of an open economy for three reasons, first is difficult to separate consumption data to the consumption of local goods and services and consumption of imported goods and services, and the second is due to the difficulty of separating data local and foreign investment, The third reason goes back to avoid addressing the matters relating to the exchange rate.

\subsubsection{The Monetary Sector}

Requests money for trade-offs, Valencod from the standpoint of Classic is a means of exchange, and is determined by the amount of money required to build the so-called equation of exchange, and this equation is part of the theory faculty that illustrate the direct relationship between money supply and the general level of prices, there are two schools of the first school of Yale, which adopted the equation of exchange and other schools that adopted the Cambridge cash balances approach and both schools believe in the function of money as a means of exchange, has added a School of Cambridge and the other function of money as a store of value. After this development in the views on the demand for money came for neo-classic confirm the essential role of money as a means of swaps and taken them but they did not explain the role of interest rate in determining the demand for money. From a Keynesian point of view, the demand for money function is divided into two parts: the demand for swaps and hedge as a function of the level of real income $\mathrm{Y}$ and the demand for highly speculative as a function of the interest rate $\mathrm{R}$ (Zubi, 2004), and therefore be a function as follows:

$$
\underline{\mathrm{M}^{\mathrm{d}}}=f(Y, R)
$$

For the purposes of the standard will be the formulation of demand for money function as a model (Bernanke, Gertler \& Gilchrist), as was derived function of the utility function that contains the work and consumption and the balance of the money, under the under the income that contain consumption and deposits of individuals in the banks and the stock of money, wages, taxes and corporate profits distributed The interest rate on deposits with respect to the balance of the money (Fukunaga, 2002), and therefore function takes the following form:

$$
M D_{t}=b_{12}+b_{13} C_{t}+b_{14} R_{t}+\varepsilon_{4}
$$

It depends positively on the private consumption $(\mathrm{Ct})$ and negatively on the interest rate $(\mathrm{Rt})$ the equation for this sector:

$$
M D=M S
$$

Indicates where MS to the money supply, has split economists in their views about the money supply Some Like unto King they see as a monetary phenomenon under the control of the monetary authority and therefore it is determined outside the model, and see others like an ant Cagen that the money supply is a reflection of the behavior of the monetary sector and real economy and therefore it shall be in addition to the monetary policy through the behavior and customs, banking for individuals and therefore the money supply is determined within the model, while Friedman believes that the money supply is a variable external if some of its components is determined within the model, as these elements do not affect the results the analysis. Since about $75 \%$ of the money supply in Jordan is under the control of the Central Bank and 25\% determined by the behavior of individuals and commercial banks (Shkukani, 2005) will be adopting the view of Friedman and the assumption that this variable is determined outside the model. 


\subsection{The Supply Side}

\subsubsection{Production Function}

The production function real expression of the relationship between the amounts of the elements used in the production process and the quantity produced which can be obtained with the assistance of these elements, are used as an analytical tool at the macro level, and is the Cobb-Douglas more functions commonly used in economic analysis, which is determined by each of the work (Ht) and capital (KKt) estimated as logarithmic as follows:

$$
\log \left(Y_{t}\right) B=b_{15} \log \left(K K_{t}\right)+b_{16} \log \left(H_{t}\right)+\varepsilon_{5}
$$

The Cobb-Douglas including:

- a (b15, b16) partial elasticities of production factors.

- If the total elasticities less than one, this indicates the diminishing economies of scale.

- If the sum of elasticities is greater than the one Fidel on the growing economies of scale.

- If the sum of elasticities is equal to one-Fidel on the economies of scale fixed.

4.2.2 Balance the Labor Market

\subsubsection{Supply of Labor}

We can reach this function depending on the model (Bernanke, Gertler and Gilchrist), which was adopted in turn, economic theory, Keynesian and modern, by derivation function, the benefit of the household sector, which contains the vacuum, work and consumption and the balance of the money, under the under the income that contain consumption and deposits of individuals in the banks and the balance of money, wages, taxes and corporate profits distributed and the interest rate on deposits with respect to work (Fukunaga, 2002), and it becomes the equation of labor supply as follows:

$$
W_{t} / C_{t}=\zeta\left(1 / 1-H_{t}\right)
$$

Indicate where (Wt) to pay, and $(\mathrm{Ht})$ to the number of hours of work, and $(\mathrm{Ct})$ to private consumption.

\subsubsection{Demand of Labor}

We have confirmed ((Fukunaga in his study, which relied on the model (Bernanke, Gertler, Gilchrist) that it can be assumed that the productivity of the worker's wage is equal to gross profit divided by the added cost as follows (Fukunaga, 2002):

$$
W_{t}=\left[1 / X_{t}\right]\left[(1-\alpha)\left(Y_{t} / H_{t}\right)\right]
$$

Indicate where (Yt) to the level of gross domestic product (GDP), and (Wt) to pay, and (Ht) to the number of hours of work, and $(\mathrm{Xt})$ added to the total profit of the cost.

The study assumes that when the balance is equal labor supply with demand, and to find the equation of balance of the labor market:

$$
\left[1 / X_{t}\right]\left[(1-\alpha)\left(Y_{t} / H_{t}\right)\right]=\zeta\left(1 / 1-H_{t}\right)
$$

And solving the equation above ((Fukunaga, 2002, take the equation of equilibrium as logarithmic work as follows:

$$
\log \left(H_{t}\right)=b_{17}+b_{18} \log \left(Y_{t}\right)+b_{19} \log \left(C_{t}\right)+b_{21} \log \quad\left(X_{t}\right)+\varepsilon_{6}
$$

It depends positively on the private consumption $(\mathrm{Ct})$ and income $(\mathrm{Yt})$ to the total profit for the added cost of Xt.

Gives the method of least squares ordinary (OLS) results inefficient if there was a correlation between Random errors in the form, and here came the idea of using the method of (3-stage), which is considered one of the most standard efficiency especially when dealing with the model as an integrated system and not Kmadelat individual, where they are in the third step of this method is the adoption of a way of seemingly unrelated regressions in the estimate, and when you make the necessary tests there was some equations in the model suffers from this problem has been these equations each of the production function and the function of work and function of investment, this has been overcome this problem by adding variables other independent of the model, it was added a variable correction factor (AR2) and variable work periods of delay and variable remuneration to a function of work, and the correction coefficient (AR1) to the production function, and variable rate of growth in output (GRt) to a function of investment. 


\section{Estimate the Results of the Form}

Has been estimated Structural formula of the model after the former to make sure all of the discrimination by a police officer class and grade, and stability through test DF and ADF in addition to the problem of the link between the random errors in the form of the test DW test H. DW of functions containing periods of delay using the method least-squares three-phase (3-stage), has been used variables and a median of variable GDP periods of delay (1) to (4) add to a variable rate of return on investment when the analysis was to use these variables as being related to the strong and direct with the equations of the form as follows

Table 3. The results of estimating parameters

\begin{tabular}{|c|c|c|c|}
\hline Parameter & code parameter & estimated & Prob \\
\hline Coefficient in the consumption function & $\mathrm{b}_{1}$ & -1226.46 & 0.064 \\
\hline $\begin{array}{l}\text { Coefficient of consumption for one period of delay in the consumption } \\
\text { function }\end{array}$ & $\mathrm{b}_{2}$ & .69 & 0.000 \\
\hline Coefficient of disposable income in the consumption function & $b_{3}$ & .53 & 0.052 \\
\hline Function in plants fixed investment & $\mathrm{b}_{4}$ & -461.94 & 0.217 \\
\hline Coefficient of volume ratio to gross domestic investment in a function & $\mathrm{b}_{6}$ & 1406.38 & 0.049 \\
\hline $\begin{array}{l}\text { Coefficient of the proportion of market capitalization to gross domestic } \\
\text { investment in a function }\end{array}$ & $\mathrm{b}_{25}$ & -361.806 & 0.376 \\
\hline $\begin{array}{l}\text { Coefficient of the proportion of facilities granted to the private sector to } \\
\text { gross domestic investment in a function }\end{array}$ & $\mathrm{b}_{24}$ & 518.083 & 0.094 \\
\hline $\begin{array}{l}\text { Coefficient of the proportion of facilities for non-financial institutions } \\
\text { to domestic credit in the investment function }\end{array}$ & $b_{23}$ & 3654.75 & 0.000 \\
\hline Interest rate coefficient in the investment function & $\mathrm{b}_{26}$ & -3.022 & 0.690 \\
\hline Coefficient of financial depth in the investment function & $\mathrm{b}_{7}$ & 79.22 & 0.338 \\
\hline Coefficient of growth rate in gross investment in a function & $\mathrm{b}_{27}$ & 1964.275 & 0.012 \\
\hline $\begin{array}{l}\text { Coefficient of the proportion of assets of the licensed banks to the } \\
\text { banking system's assets in the investment function }\end{array}$ & $\mathrm{b}_{5}$ & -461.94 & 0.217 \\
\hline Function in plants fixed government consumption & $\mathrm{b}_{8}$ & -388.207 & 0.010 \\
\hline Coefficient of income in the government consumption & b9 & .271 & 0.001 \\
\hline Tax coefficient in function of government consumption & $b_{10}$ & .2086 & 0.282 \\
\hline Coefficient of government consumption for one lag & $\mathrm{b}_{11}$ & .436 & 0.020 \\
\hline Coefficient in the fixed demand for money function & $b_{12}$ & 70.864 & 0.915 \\
\hline Coefficient of consumption in the demand for money function & $b_{13}$ & 0.106 & 0.689 \\
\hline Interest rate coefficient in the demand for money function & $\mathrm{b}_{14}$ & -30.514 & 0.411 \\
\hline Coefficient of capital in the production function & $\mathrm{b}_{15}$ & -0.258 & 0.415 \\
\hline Coefficient of work in the production function & $\mathrm{b}_{16}$ & 1.257 & 0.000 \\
\hline Coefficient correction factor in the production function & $\mathrm{b}_{22}$ & 0.668 & 0.000 \\
\hline $\begin{array}{l}\text { (Coefficient of income } * \text { coefficient of the consumption) } \div \text { the } \\
\text { coefficient of gross profit added to the cost }\end{array}$ & $b_{18}$ & 0.092 & 0.000 \\
\hline Coefficient correction factor in the labor function & $\mathrm{b}_{28}$ & 0.350 & 0.054 \\
\hline Coefficient of labor function with two lags periods & $\mathrm{b}_{29}$ & 1.257 & 0.000 \\
\hline Wage coefficient in the labor function & $\mathrm{b}_{30}$ & -0.197 & 0.000 \\
\hline
\end{tabular}

To achieve the purposes of this study to clarify the role of financial institutions in influencing the levels of investment in Jordan, we will focus in this area a function of investment, that the results of careful appreciation of the standard can be noted that the results of the assessment of the model came to show:

First: The results of the test $(\mathrm{F})$ to the moral high statistical model equations estimated. 
Second, according to the values of the multi-rate coefficient of determination (AdR2) or the so-called quality factor of Conformity:

A-about $96 \%$ of the changes in private consumption in Jordan has been explained by the independent variables for the consumption function.

B-about $95 \%$ of the changes in private investment in Jordan has been explained by the independent variables of a function of investment.

C-about $97 \%$ of the changes in government consumption in Jordan has been explained by the independent variables for the function of government consumption.

D-about $98 \%$ of the changes in the demand for money in Jordan was explained by the independent variables of the demand for money function.

E-about $95 \%$ of the changes in production in Jordan has been explained by the independent variables of the production function.

F-about $99 \%$ of the changes in the labor market in Jordan has been explained by the independent variables of the function the labor market.

Third, according to the parameter values estimated in the model and the statistical significance of results of the estimation of investment function to confirm:

A positive significant effect of the proportion of credit facilities granted to non-financial institutions from the private sector to total domestic credit facilities (PRt) under 5\% level of significance, and this result was consistent with the findings of the study (Levine, 1993).

1) There is no impact to the proportion of credit facilities granted to the private sector to the gross domestic product (PRVt) under the level of significance of 5\%, but it has had an impact positive under the level of significance $10 \%$, the study found (Soufan, 2008) to the existence of the impact of positive and moral for this variable on the growth of output.

2) There is no impact to the rate of rotation, represented by the annual turnover for the total market value of women's $(\mathrm{Vt})$ under the $5 \%$ level of significance, the relationship was negative and that's OK of the findings of the study (Soufan, 2008).

3) Under the 5\% level of significance there is to influence the proportion of assets of the licensed banks to the total assets of licensed banks (Bt).

4) There is no impact to the variable of financial depth (Dt) under the $5 \%$ level of significance, and this was contrary to the study (Soufan, 2008).

5) A positive effect for the volume percentage of GDP (RRt) under the 5\% level of significance, and this is OK, the findings of the study (Soufan, 2008).

6) There is no significant effect of the interest rate in Jordan under the 5\% level of significance, and this is compatible with all studies that addressed the impact of the interest rate on investment in Jordan.

\section{Results and Recommendations}

The results of estimating the standard model, emphasizing the important role played by financial institutions to influence the levels of investment in Jordan, where the results show a positive effect of the banking system at the level of investment in Jordan during the study period, stressing that the role played by banks in the allocation and channeling the savings of society through indicators of the proportion of assets of the licensed banks to the total assets of licensed banks and the Central Bank, and the proportion of credit facilities granted to institutions of non-financial private sector to total credit facilities granted to the private sector to GDP, which leads us to accept the first hypothesis, which says that the levels of investment affected by the extent and existence of advanced banking financial institutions. The results show the positive impact of the development of the financial levels of investment in Jordan, through the indicators of volume of the annual proportion of the total market value of the annual, and trading volume relative to GDP, and this leads to accept the second hypothesis to the effect that the levels of investment in Jordan are affected the extent and existence of a market securities advanced. Thus, the study recommends that the decision maker should be given the role of the financial sector first and foremost in terms of development control and that of the critical importance played by financial institutions and their role in influencing the investment and thus to make a Jordanian business cycles. 


\section{References}

Abu-Ghazaleh, R. (1991). The impact of institutions of financial intermediation on economic growth in Jordan for the period (68-88). Unpublished MA Thesis, Yarmouk University.

Alalaween, M. (1998). The impact of bank credit in bringing about economic fluctuations in Jordan (1972-1996). Unpublished Master Thesis, University of Jordan.

Al-Majali, A. (2003). The impact of bank credit on economic activity in Jordan: VAR model during the period (1970-2000). Unpublished MA Thesis, University of Mutah.

Al Zoubi, B., \& Alsawai, K. (2004). The demand function for money in Jordan. Studies, Management Science Journal, 31 .

Athamny, A. B. (2006). Macro-economic effects of labor migration: an analytical study of the situation of Jordan, (1973-2004). PhD. thesis, University of Jordan.

Classsens, L. (2003). Financial development, property rights, and growth. World Bank working paper.

Fukunaga, I. (2002). Financial Accelerator Effects in Japan's Business Cycles. Bank of Japan Working Paper.

Friedman, M. (1956). The Quantity Theory of Money: A Restatement in Studies in Quantity Theory of Money. Chicago: University of Chicago Press.

Fisman, R. (2004). Financial development and growth in the short and long run. World Bank working paper.

Hall, S. (2001). Financial Accelerator Effects in UK Business Cycles. Bank England Working Paper.

Hall, S., \& Wetherilt, A. V. (2001). The Role of Corporate Balance Sheets and Bank Lending Policies in a Financial Accelerator Framework. Bank of England Working Paper.

Ireland, P. N. (2001). Sticky-Price Models of the Business Cycle: Specification and Stability. Journal of Monetary Economics. http://dx.doi.org/10.1016/S0304-3932(00)00047-7

Kiswani, M. (1997). An Empirical Study of the behavior of investment in the Syrian Arab Republic. Journal of Damascus University, 13(1).

King, R. G. (1993). Will the New Keynesian Macroeconomics Resurrect the IS-LM Model? The Journal of Economic Perspectives. http://dx.doi.org/10.1257/jep.7.1.67

King, L. (1993). Finance and growth: Schumpeter might be right. The Quarterly Journal of Economic, 108(3), World paper.

Levine, R. (1997). Financial Development and Economic Growth. Journal of Economic Literature, 35(2), $688-726$.

Love, I. (2002). Financial development and dynamic investment behavior: evidence from vector Auto regression. working paper, World Bank.

Lucas \& Robert, E. Jr. (1980). Methods and Problems in Business Cycle Theory. Journal of Money, Credit, and Bunking.

Paddar, T., Sab, R., \& Khachatryan, H. (2006). The Monetary Transmission Mechanism In Jordan. IMF working paper.

Alao, O., \& Raimi, L. (2011) Global economic melt-down and the role of financial institutions: Lessons from South Africa for policymakers in Nigeria. Humanomics, 27(3), 201-211. http://dx.doi.org/10.1108/08288661111165231

Quraan, A. A. (1988). Macroeconomic Effects of Workers' Remittances: The case of Jordan. phD. dissertation University of Texas at Dallas.

Serry, E. A. (1987). A Macro econometric Model for the Egyptian Economy, Specification, estimation and Simulation under alternative principles of economics. Clark University, Worcester, Massachusetts.

Shkukani, H. (2005). The impact of fiscal and monetary policy on economic growth in Jordan. Unpublished MA Thesis, University of Jordan.

Soufan, T. (2008). The impact of financial sector development on economic growth in Jordan for the period (1978-2004). PhD unpublished thesis, University of Jordan.

Tang, D. (2006). The effect of financial development on economic growth: evidence from the APEC countries, 1981-2000. Applied Economics, 38(16). http://dx.doi.org/10.1080/00036840500427239 


\section{Copyrights}

Copyright for this article is retained by the author(s), with first publication rights granted to the journal.

This is an open-access article distributed under the terms and conditions of the Creative Commons Attribution license (http://creativecommons.org/licenses/by/3.0/). 